\title{
Assessment of Undiscovered Oil and Gas Resources in the Bossier Formation, U.S. Gulf Coast, 2016
}

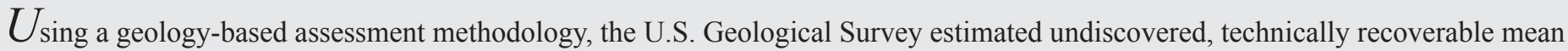
resources of 2.9 billion barrels of conventional oil and 108.6 trillion cubic feet of natural gas in the Upper Jurassic Bossier Formation in onshore lands and State waters of the U.S. Gulf Coast region.

\section{Introduction}

The U.S. Geological Survey (USGS) assessed undiscovered, technically recoverable oil, gas, and natural gas liquids in the Upper Jurassic Bossier Formation and stratigraphically equivalent units in the subsurface of the Gulf Coast from south Texas to the Florida Panhandle (fig. 1). The Bossier Formation is part of the Upper Jurassic-CretaceousTertiary Composite Total Petroleum System (TPS) in onshore lands and State waters of the U.S. Gulf Coast region. Strata in each assessment unit (AU) within a TPS share similar stratigraphic, structural, and petroleum-charge histories.

\section{Geologic Models for Assessment}

Mudstones within the Upper Jurassic Smackover, Haynesville, and Bossier Formations are sources of oil and gas in both conventional (Montgomery 1993a, 1993b, 2001; Mancini and others, 2006; Goddard and others, 2008) and continuous reservoirs (Hammes and Frébourg, 2012; Cicero and Steinhoff, 2013) in much of the assessment area. Conventional sandstone reservoirs in the Bossier Formation were deposited in marginal marine and marine shelf, slope, and basin floor depositional settings. Continuous mudstone reservoirs of the Bossier Formation are located basinward of Bossier Formation and Cotton Valley Group sandstones.

\section{Assessment Units}

Three of the four Bossier Formation AUs were quantitatively assessed (fig. 1). Parts of the two conventional AUs overlap the continuous AUs. Table 1 lists input data used to calculate volumes of undiscovered resources in the three AUs.

The Bossier Western Shelf Sandstone Gas AU is defined by faults on the north and west and lithofacies extending east into the East Texas Basin (Salvador, 1991; Klein and Chaivre, 2002; Cicero and Steinhoff, 2013). Reservoirs transition from fluviodeltaic in the west to shelf, slope, and basin floor fans to the east (Montgomery, 2001).

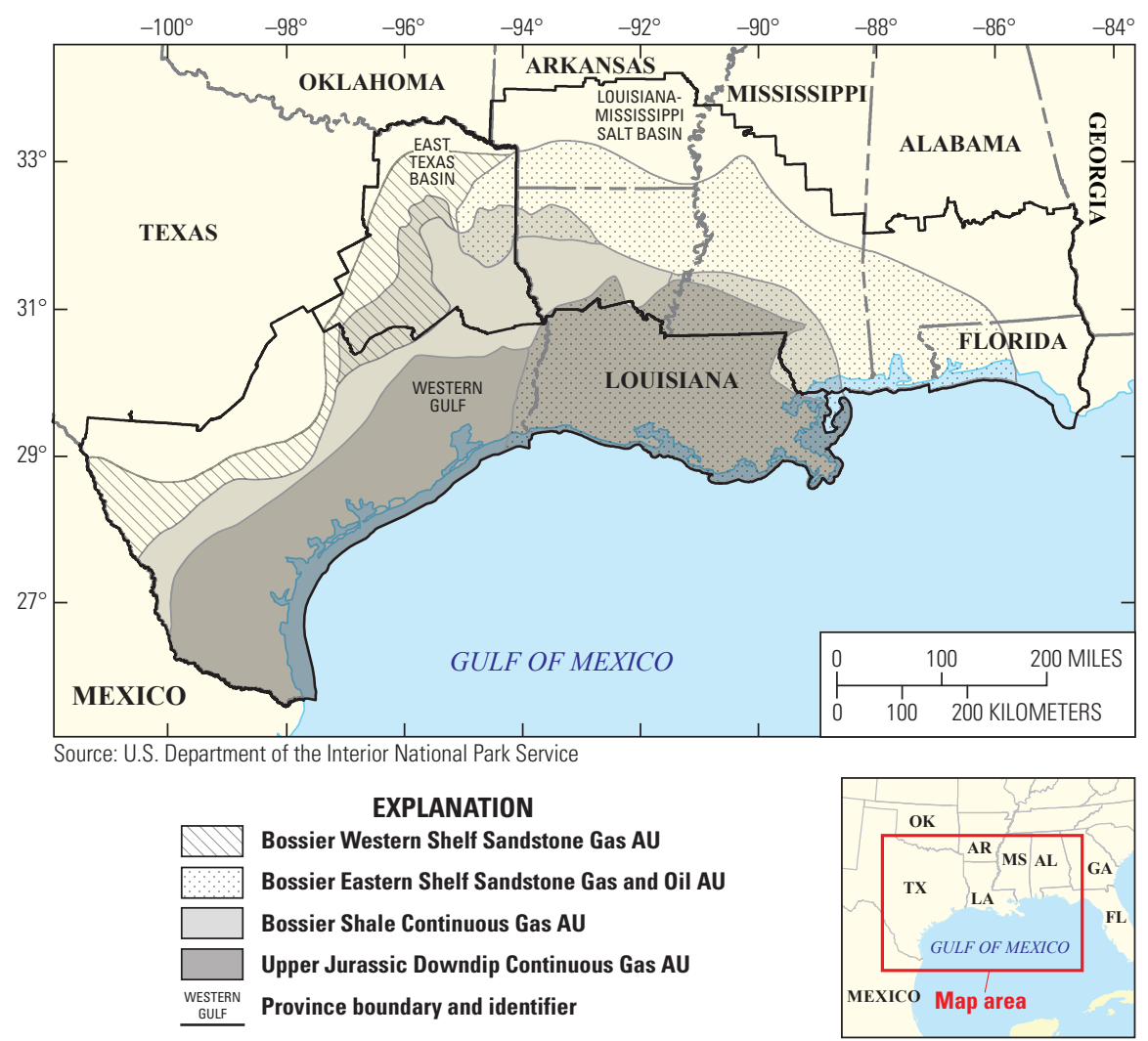

Figure 1. Map showing approximate boundaries for the four assessment units (AUs) in the Upper Jurassic Bossier Formation.

The Bossier Eastern Shelf Sandstone Gas and Oil AU is defined by faults on the northeast and lithofacies extending southwest to the continental shelfbreak and beyond (Salvador, 1991; Cicero and Steinhoff, 2013). Reservoirs transition from fluviodeltaic and paralic in the east to fans on the shelf, slope, and basin floor to the southwest (Cicero and Steinhoff, 2013, fig. 12).

The Bossier Shale Continuous Gas AU is defined by mudstones interbedded with and basinward of Bossier Formation sandstones and Cotton Valley Group sandstones (Salvador, 1991; Hammes and Frébourg, 2012; Cicero and Steinhoff, 2013). The southern boundary of the mudstone is the continental shelf-break.

The Bossier Formation south of the continental shelf-break is assigned to an Upper Jurassic Downdip Continuous Gas AU that was not assessed. This AU is an amalgamation of Smackover, Haynesville, and Bossier Formation mudstones. 


\section{Undiscovered Resources Summary}

The USGS assessed undiscovered, technically recoverable resources for two conventional AUs and one continuous AU in the Bossier Formation. The estimated mean totals for oil and gas resources are 2,854 million barrels of oil (MMBO), or 2.9 billion barrels of oil, with an F95-F5 range from 1,193 to 5,147 MMBO; 108,587 billion cubic feet of gas (BCFG), or 108.6 trillion cubic feet of gas, with an F95-F5 range from 37,162 to 223,472 BCFG; and 1,052 million barrels of natural gas liquids (MMBNGL) with an F95-F5 range from 424 to 2,009 MMBNGL (table 2).

Table 1. Key assessment input data for three assessment units (AUs) in the Bossier Formation of Alabama, Arkansas, Florida, Louisiana, Mississippi, and Texas.

[The Upper Jurassic Downdip Continuous Gas AU was not quantitatively assessed in this study. AU, assessment unit; \%, percent; EUR, estimated ultimate recovery per well; $\mathrm{MMBO}$, million barrels of oil; $\mathrm{BCFG}$, billion cubic feet of gas. The average EUR input is the minimum, median, maximum, and calculated mean. Shading indicates not applicable]

\begin{tabular}{|c|c|c|c|c|}
\hline \multirow[b]{2}{*}{ Assessment input data } & \multicolumn{4}{|c|}{ Bossier Western Shelf Sandstone Gas AU } \\
\hline & Minimum & Median & Maximum & $\begin{array}{c}\text { Calculated } \\
\text { mean }\end{array}$ \\
\hline \multicolumn{5}{|l|}{ Number of oil fields } \\
\hline Number of gas fields & 1 & 80 & 300 & 87.4 \\
\hline \multicolumn{5}{|l|}{ Sizes of oil fields (MMBO) } \\
\hline Sizes of gas fields (BCFG) & 3 & 6 & 4,000 & 38.1 \\
\hline AU probability & 1.0 & & & \\
\hline \multirow[b]{2}{*}{ Assessment input data } & \multicolumn{4}{|c|}{ Bossier Eastern Shelf Sandstone Gas and Oil AU } \\
\hline & Minimum & Median & Maximum & $\begin{array}{c}\text { Calculated } \\
\text { mean }\end{array}$ \\
\hline Number of oil fields & 1 & 200 & 500 & 208.7 \\
\hline Number of gas fields & 1 & 400 & 1,000 & 417.3 \\
\hline Sizes of oil fields (MMBO) & 0.5 & 1.5 & 1,600 & 13.6 \\
\hline Sizes of gas fields (BCFG) & 3 & 18 & 10,000 & 118.1 \\
\hline AU probability & 1.0 & & & \\
\hline \multirow[b]{2}{*}{ Assessment input data } & \multicolumn{4}{|c|}{ Bossier Shale Continuous Gas AU } \\
\hline & Minimum & Mode & Maximum & $\begin{array}{c}\text { Calculated } \\
\text { mean }\end{array}$ \\
\hline Potential production area of AU (acres) & 20,000 & $5,612,000$ & $25,921,000$ & $10,517,667$ \\
\hline Average drainage area of wells (acres) & 60 & 100 & 180 & 113 \\
\hline Success ratio $(\%)$ & 10 & 50 & 90 & 50 \\
\hline Average EUR (BCFG) & 0.5 & 1.0 & 3.0 & 1.109 \\
\hline AU probability & 1.0 & & & \\
\hline
\end{tabular}

\section{References Cited}

Cicero, A.D., and Steinhoff, Ingo, 2013, Sequence stratigraphy and depositional environments of the Haynesville and Bossier shales, east Texas and north Louisiana, chap. 3 of Hammes, Ursula, and Gale, Julia, eds., Geology of the Haynesville gas shale in east Texas and west Louisiana, U.S.A.: American Association of Petroleum Geologists Memoir 105, p. $25-46$.

Goddard, D.A., Mancini, E.A., Horn, M.R., and Talukdar, S.C., 2008, Hydrocarbon generating potential—Jurassic Cotton Valley_-Bossier Group, north Louisiana Salt Basin: Gulf Coast Association of Geological Societies Transactions, v. 58 , p. $305-325$.

Hammes, Ursula, and Frébourg, Gregory, 2012, Haynesville and Bossier mudrocks - A facies and sequence stratigraphic investigation, east Texas and Louisiana, USA: Marine and Petroleum Geology, v. 31, no. 1, p. 8-26.

Klein, G.D., and Chaivre, K.R., 2002, Sequence and seismic stratigraphy of the Bossier Formation (Tithonian), western east Texas Basin: Gulf Coast Association of Geological Societies Transactions, v. 52, p. 551-561.

Mancini, E.A., Peng, Li, Goddard, D.A., and Zimmerman, R.K., 2006, Petroleum source rocks of the onshore interior salt basins, north central and northeastern Gulf of Mexico: Gulf Coast Association of Geologic Societies Transactions, v. 55 , p. $486-504$.

Montgomery, Scott, 1993a, Cotton Valley lime of east Texas-New pinnacle reef play in the Late Jurassic: Petroleum Frontiers, v. 10, no. 2, 55 p.

Montgomery, Scott, 1993b, Haynesville of southern Alabama-A new Jurassic play in the eastern Gulf: Petroleum Frontiers, v. 10, no. 1, 65 p.

Montgomery, Scott, 2001, East Texas Basin Bossier gas play: Petroleum Frontiers, v. 17, no. 2, 64 p.

Salvador, Amos, 1991, Triassic-Jurassic, in Salvador, Amos, ed., The Gulf of Mexico Basin, part of The geology of North America: Boulder, Colo., The Geological Society of America, v. J, p. 131-180.

Table 2. Assessment results for three assessment units (AUs) in the Bossier Formation of Alabama, Arkansas, Florida, Louisiana, Mississippi, and Texas.

[MMBO, million barrels of oil; BCFG, billion cubic feet of gas; NGL, natural gas liquids; MMBNGL, million barrels of natural gas liquids. Results shown are fully risked estimates. For gas accumulations, all liquids are included in the NGL (natural gas liquids) category. F95 represents a 95-percent chance of at least the amount tabulated; other fractiles are defined similarly. Fractiles are additive under the assumption of perfect positive correlation. Shading indicates not applicable]

\begin{tabular}{|c|c|c|c|c|c|c|c|c|c|c|c|c|c|c|}
\hline \multirow{3}{*}{$\begin{array}{l}\text { Total petroleum system and } \\
\text { assessment units (AUs) }\end{array}$} & \multirow{3}{*}{$\begin{array}{c}\text { AU } \\
\text { probability }\end{array}$} & \multirow{3}{*}{$\begin{array}{l}\text { Accumulation } \\
\text { type }\end{array}$} & \multicolumn{12}{|c|}{ Total undiscovered resources } \\
\hline & & & \multicolumn{4}{|c|}{ Oil (MMBO) } & \multicolumn{4}{|c|}{ Gas (BCFG) } & \multicolumn{4}{|c|}{ NGL (MMBNGL) } \\
\hline & & & F95 & F50 & F5 & Mean & F95 & F50 & F5 & Mean & F95 & F50 & F5 & Mean \\
\hline \multicolumn{15}{|c|}{ Upper Jurassic-Cretaceous-Tertiary Composite Total Petroleum System } \\
\hline Bossier Western Shelf Sandstone Gas AU & 1.0 & Gas & & & & & 895 & 2,844 & 7,452 & 3,342 & 6 & 21 & 61 & 26 \\
\hline \multirow{2}{*}{$\begin{array}{l}\text { Bossier Eastern Shelf Sandstone Gas } \\
\text { and Oil AU }\end{array}$} & \multirow[b]{2}{*}{1.0} & Oil & 1,193 & 2,670 & 5,147 & 2,854 & 1,609 & 3,660 & 7,435 & 3,990 & 165 & 375 & 763 & 409 \\
\hline & & Gas & & & & & 25,248 & 46,986 & 81,196 & 49,331 & 228 & 437 & 778 & 461 \\
\hline Total conventional resources & & & 1,193 & 2,670 & 5,147 & 2,854 & 27,752 & 53,490 & 96,083 & 56,663 & 399 & 833 & 1,602 & 896 \\
\hline Bossier Shale Continuous Gas AU & 1.0 & Gas & & & & & 9,410 & 42,124 & 127,389 & 51,924 & 25 & 120 & 407 & 156 \\
\hline Upper Jurassic Downdip Continuous Gas AU & & Gas & \multicolumn{12}{|c|}{ Not quantitatively assessed } \\
\hline Total continuous resources & & & & & & & 9,410 & 42,124 & 127,389 & 51,924 & 25 & 120 & 407 & 156 \\
\hline Total undiscovered resources & & & 1,193 & 2,670 & 5,147 & 2,854 & 37,162 & 95,614 & 223,472 & 108,587 & 424 & 953 & 2,009 & 1,052 \\
\hline
\end{tabular}

\section{For More Information}

Assessment results are available at the USGS Energy Resources Program website at http://energy.usgs.gov.

\section{Bossier Formation Assessment Team}

Stanley T. Paxton, Janet K. Pitman, Scott A. Kinney, Nicholas J. Gianoutsos, Ofori N. Pearson, Katherine J. Whidden, Russell F. Dubiel, Christopher J. Schenk, Lauri A. Burke, Timothy R. Klett, Heidi M. Leathers-Miller, Tracey J. Mercier, Seth S. Haines, Brian A. Varela, Phuong A. Le, Thomas M. Finn, Stephanie B. Gaswirth, Sarah J. Hawkins, Kristen R. Marra, and Marilyn E. Tennyson 